\title{
Penguatan Kelembagaan dan Pengembangan Potensi Ekonomi Masyarakat melalui Pengelolaan Saluran Irigasi Menjadi Wisata Literasi pada Kelompok Budidaya Ikan (POKDAKAN) “Banyu Bening” Jajag Banyuwangi
}

\author{
Nurul Inayah \\ Institut Agama Islam Darussalam \\ Blokagung Banyuwangi \\ E-mail: ninailzam2015@gmail.com \\ M. Rizkon Al Musafiri \\ Institut Agama Islam Darussalam \\ Blokagung Banyuwangi \\ E-mail: m.rizqon.almusafiri@gmail.com
}

\author{
Nawal Ika Susanti \\ Institut Agama Islam Darussalam \\ Blokagung Banyuwangi \\ E-mail: nawalika@iaida.ac.id
Lely Ana Ferawati Ekaningsih
Institut Agama Islam Darussalam
Blokagung Banyuwangi
E-mail: lafwens@gmail.com

\section{Article History:}

Received: 2019-10-16

Revised: 2020-04-17

Accepted: 2020-05-31
Keywords: Asset-Based

Community Development

$(A B C D)$, Fish Farming

Development, Literacy

Tourism

\begin{abstract}
Banyu Bening" fish village has the potential to become an alternative of literacy tourism and can be developed to increase the economic income for the local community, especially the porters. One of the obstacles faced was the conflict between management and the managerial from POKDAKAN which made the condition of "Banyu Bening" fish village was not optimal. Therefore, by fostering institutional strengthening in the "Banyu Bening" fish village, it is hoped that this potential can be used as an alternative for literacy tourism. This community service was based on Asset-Based Community Development (ABCD) approach and was implemented through training on the development of literacy culture based on local potential and conducting FGDs for institutional strengthening. The program has resulted in improved management of POKDAKAN and optimizing economic improvement through fish farming development in the irrigation water as well as media of education for litearcy tourism.
\end{abstract}

\section{Pendahuluan}

Pindar, Filosof Yunani abad V SM. menyatakan "air adalah yang terbaik dari segalanya" dan Empedocles (490-430) juga menyatakan "air adalah elemen utama disamping udara, api, bumi"1. Hal ini mendandakan bahwa air memberikan kontribusi yang sangat penting bagi kehidupan, baik bagi alam mapun bagi manusia. Oleh karena itu, maka sumber daya air harus dimanfaatkan sebaik mungkin dalam kehidupan ini. Menurut Sunaryo, sumberdaya air adalah air dan semua potensi yang terdapat pada air,

${ }^{1}$ Hadimulyono M.B., “Kebijakan Pengeloaan Suberdaya Air Menurut Undang-Undang Tengtang Sumber Daya Air Dalam Perepesktif Menunjang Pembanguan Pertanian” (Bogor: Deptan Bogor, 2004). 
sumber air, termasuk sarana dan prasarana pengairan yang dapat dimanfaatkan, namun tidak termasuk kekayaan hewani yang ada di dalamnya. ${ }^{2}$

Pengelolaan sumberdaya air adalah upaya merencanakan, melaksanakan, memantau dan mengevaluasi penyelenggaraan konservasi sumberdaya air, pendayagunaan sumberdaya air, dan pengendalian daya rusak air. Adapun visi dan misi pengelolaan sumberdaya air adalah mewujudkan kemanfaatan sumberdaya air bagi kesejahteraan seluruh rakyat dan konservasi sumberdaya air yang adil untuk berbagai kebutuhan masyarakat. Salah satu tujuan pengelolaan sumberdaya air adalah mendukung pembangunan regional dan nasional yang berkelanjutan dengan mewujudkan keberlanjutan sumberdaya air. ${ }^{3}$

Salah satunya sebagaimana yang dilakukan oleh masyarakat Banyu Bening, Desa Jajag yang memanfaatkan air irigasi menjadi manfaat ganda dan multifungsi bagi masyarakat, yakni selain menjadi air irigasi ke persawahan juga mampu dikembangkan menjadi wisata literasi.

Berawal dari keprihatinan akan lingkungan yang kurang bersih terutama saluran air di sekitar rumah Bapak Muyadi mengajak teman-teman disekitar RT 4 dan RT 6 dusun Krajan Desa Jajag Gambiran Banyuwangi berbincang ringan tentang cara untuk memanfaatkan saluran air irigasi yg sering kotor oleh sampah. Akhirnya Bapak Muyadi bersama masyarakat yang sebagian besar berprofesi buruh panggul membentuk Kelompok Pembudidaya Ikan (POKDAKAN) "Banyu Bening" Desa Jajag, pada bulan Februari 2018.

Komunitas buruh panggul tersebut membuat kampung ikan dengan pengelola masyarakat sekitar RT 04 dan RT 06 dusun Krajan Jajag Gambiran Banyuwangi. Lokasi kampung ikan "Banyu Bening" ini memang dekat DAM irigasi pertanian yang ada di Desa Jajag, jadi persediaan air yang mengalir tidak menjadi masalah. Program ini juga telah diperkuat oleh Peraturan Desa (Perdes) No.1 Tahun 2008 yang telah ditetapkan sebelumnya untuk mengatur tentang pelarangan warga untuk melakukan penyetruman, menjala ikan, dan penggunaan obat-obatan disepanjang irigasi sungai desa. ${ }^{4}$

Sejalan dengan perkembangan waktu, kampung ikan di respon masyarakat dengan baik. Jika sore hari dan hari libur, kampung ikan "Banyu Bening" menjadi ramai dengan anak-anak yang bermain dan pengelola juga menyediakan buku-buku bacaan yang berasal dari sumbangan perpustakaan dari Pemerintah Kabupaten Banyuwangi dengan tujuan untuk meningkatkan minat baca pengunjung dan juga dapat memberi wawasan tentang memelihara lingkungan yang bersih dari sampah. Luas area kampung ikan ini adalah $103 \mathrm{~m}^{2}$ dan saat ini sudah berisi 23.000 ikan. Selain itu, kampung ikan

2 I K Dewi, “Model Pengelolaan Kawasan Permukiman Berkelanjutan Di Daerah Aliran Sungai

(DAS) Ciliwung Hulu Kabupaten Bogor" (Doctoral Dissertation, Institut Pertanian Bogor, 2010).

3 Ibid.

${ }^{4}$ Kepala Desa Jajag Gambiran Banyuwangi, Peraturan Desa Jajag Gambiran Banyuwangi No.1 Tahun 2008 Tentang Pelarangan Warga Untuk Melakukan Penyetruman, Menjala Ikan, Dan Penggunaan Obat-Obatan Disepanjang Irigasi Sungai Desa (Indonesia, 2008). 
"Banyu Bening" ini juga menjadi tempat tujuan bagi pelajar dari TK hingga SMA untuk belajar tentang pembudidayaan ikan air tawar sehingga bisa menjadi alternatif wisata literasi di daerah Banyuwangi.

Setelah melakukan observasi ada beberapa kondisi yang memprihatinkan, bukubuku yang didapat dari sumbangan perpustakaan Kabupaten sudah sangat berkurang jumlahnya serta tidak terawat dengan baik. Hal ini dapat disebabkan karena kurangnya pengawasan dari pengelola sehingga buku-buku tersebut terbawa oleh pengunjung. Kampung ikan "Banyu Bening" berpotensi untuk menjadi salah satu alternatif wisata literasi dan sekaligus dapat dikembangkan untuk bisa menambah penghasilan secara ekonomi bagi masyarakat sekitar dengan cara menjual makanan ikan yang dapat dibeli oleh pengunjung. Ketika sudah waktunya panen, masyarakat sekitar dapat menjual ikan bakar di sekitar saluran irigasi.

Salah satu kendala saat ini adalah adanya konflik antara manajemen dan kepengurusan dari POKDAKAN, maka kondisi kampung ikan "Banyu Bening" saat ini masih belum maksimal dalam pengelolaannya. Berdasarkan hasil studi awal, didapatkan data-data permasalahan manajemen POKDAKAN sebagai berikut: (1) Manajemen pengelolaan POKDAKAN kurang bagus, dikarenakan masih belum pahamnya anggota tentang manajemen pengelolaan pemeliharaan ikan secara professional; (2) Kepengurusan POKDAKAN terlibat konflik dengan para anggota antara satu dengan yang lain terkait tanggung jawab pengelolaan. Anggota rata-rata adalah buruh panggul, maka lokasi "Banyu Bening" sering terlihat terbengkalai, dikarenakan sering ditinggal pengurus untuk bekarja buruh panggul; (3) Potensi air yang tersedia masih belum maksimal dimanfaatkan; (4) kampung ikan "Banyu Bening" saat pembukaan memiliki buku-buku sebagai sarana literasi bagi pengunjung yang disumbang oleh pihak perpustakaan Kabupaten Banyuwangi, tapi saat ini kondisinya terbelengkai dikarenakan tidak adanya perhatian dari pengurus POKDAKAN "Banyu Bening"; dan (5) Untuk menjadi salah satu alternatif wisata literasi tentang pembudidayaan ikan air tawar, pengurus POKDAKAN masih memiliki kemampuan yang minim untuk menjadi pemandu wisata literasi yang dapat menjelaskan secara terperinci proses pembudidayaan ikan air tawar.

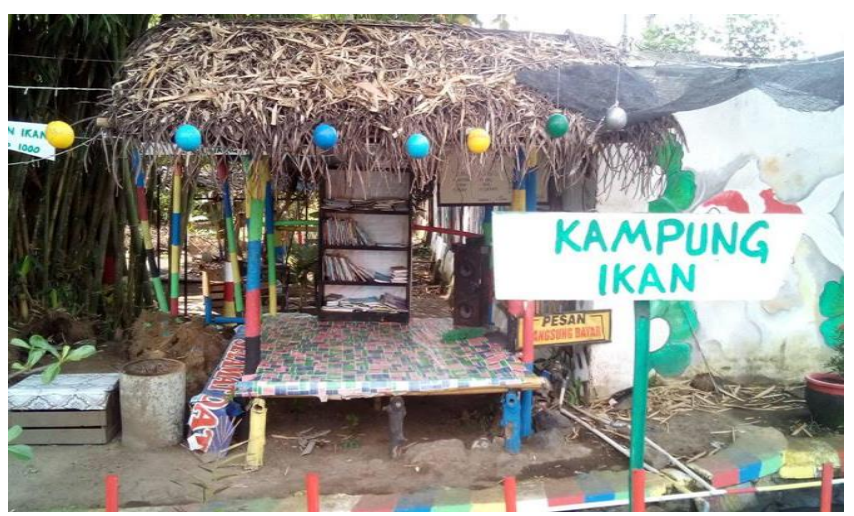

Gambar 1. Kondisi Perpustakaan Kampung Ikan "Banyu Bening” yang Memprihatinkan 
Oleh karena itu, maka melalui penguatan kelembagaan dan pengembangan potensi ekonomi masyarakat melalui pengelolaan saluran irigasi menjadi wisata literasi bersama komunitas buruh panggul di Desa Jajag Banyuwangi diharapkan dapat menjadikan kampung ikan "Banyu Bening" ini sebagai salah satu alternatif wisata literasi yaitu bagaimana mengenal budidaya ikan dan menumbuhkan gemar membaca di masyarakat sekitar.

\section{Metode}

Kegiatan pengabdian bersama komunitas kelompok pembudidaya ikan (POKDAKAN) "Banyu Bening" desa Jajag kecamatan Jajag Kabupaten Banyuwangi ini menggunakan Paradigma dan prinsip pendekatan ABCD (Asset Based Community Development) mengisyaratkan penyadaran akan keberadaan kekuatan dan energi positif yang dimiliki "masyarakat" yang harus diidentifikasi, diketahui, difahami, diinternalisasi, untuk kemudian dimobilisasi oleh masyarakat sendiri dalam kerangka menuju peningkatan kesejahteran dan keberdayaan semua elemen komunitasmasyarakat. Pada dasarnya prinsip-prinsip dalam pendekatan ABCD adalah sebagai berikut:

\section{Penemuan Apresiatif (Apreciative Inquiry)}

Secara bahasa appreciative inquiry terdiri dari kata Ap-pre"ci-ate, (apresiasi): menghargai; melihat yang paling baik pada seseorang atau dunia sekitar kita; mengakui kekuatan, kesuksesan, dan potensi masa lalu dan masa kini; memahami hal-hal yang memberi hidup (kesehatan, vitalitas, keunggulan) pada sistem yang hidup 5 .

Appreciative Inquiry (AI) dikembangkan pada tahun 1980an oleh David Cooperrider, seorang profesor di Weatherhead School of Management di Case Western Reserve University. AI dikembangkan sebagai sebuah model baru untuk pengembangan organisasi dan perubahan. Appreciative di sini dimaknai sebagai pengakuan dan peningkatan nilai. Ini adalah masalah penegasan terhadap kekuatan masa lalu dan saat ini, pengakuan terhadap aset-aset dan potensi-potensi yang dimiliki. Sedangkan istilah Inquiry merujuk kepada eksplorasi dan penemuan. Ini adalah tentang menyampaikan pertanyaan, studi dan pembelajaran.

Appreciative Inquiry (AI) adalah cara yang positif untuk melakukan perubahan organisasi berdasarkan asumsi yang sederhana yaitu bahwa setiap organisasi memiliki sesuatu yang dapat bekerja dengan baik, sesuatu yang menjadikan organisasi hidup, efektif dan berhasil, serta menghubungkan organisasi tersebut dengan komunitas dan stakeholdernya dengan cara yang sehat.

Bersama POKDAKAN "Banyu Bening" dimulai dengan mengidentifikasi hal-hal positif dan menghubungkannya dengan cara yang dapat memperkuat energi dan visi untuk melakukan perubahan untuk mewujudkan masa depan organisasi yang lebih

5 Nadhir Salahuddin, "Panduan KKN ABCD UIN Sunan Ampel Surabaya Asset Based CommunityDriven Development (ABCD)” (Surabaya: LP2M UIN Sunan Ampel Surabaya, 2015). 
baik. Berdasarkan hasil wawancara yang telah dilakukan pada penemuan apresiatif (Apreciative Inquiry) sebagaimana Tabel 1.

Tabel 1. Temuan awal asset pada POKDAKAN Banyu Bening

\begin{tabular}{cll}
\hline No & \multicolumn{1}{c}{ Hasil Observasi } & \multicolumn{1}{c}{ Skala Prioritas } \\
\hline 1 & Edukasi peduli lingkungan & $\begin{array}{l}\text { Kesadaran menjaga ekosistem dan } \\
\text { simbiosis mutualisme }\end{array}$ \\
\hline 2 & Ikan sebagai objek budidaya & $\begin{array}{l}\text { Pengembangbiakan ikan } \\
\text { Menjual ikan umur 6 bulan dari } \\
\text { masa pembibitan }\end{array}$ \\
\hline $\begin{array}{l}\text { saluran irigasi sebagai media } \\
\text { pengembangbiakan ikan }\end{array}$ & $\begin{array}{l}\text { Membuka cakrawala pengetahuan } \\
\text { Perpustakaan sebagai aset kesadaran } \\
\text { literasi masyarakat }\end{array}$ & Kesadaran interaksi sosial \\
\hline 5 & $\begin{array}{l}\text { Spiritual sebagai wadah perekat sosial } \\
\text { kemasyarakatan }\end{array}$ & \\
\hline
\end{tabular}

Sumber : wawancara Langsung pada Komunitas Banyu Bening, 2019

Pada Tabel 1. dapat dijelaskan bahwa masyarakat yang bergabung di kelompok pembudidaya ikan (POKDAKAN) "Banyu Bening" dusun Krajan desa Jajag memiliki saluran irigasi yang berada di depan rumah mengalir dari arah barat dam Kantor Pos menuju arah timur melintasi perbatasan desa Wringinagung dan Desa Jajag. pada awalnya saluran irigasi sangat kotor, sebagai tempat pembuangan sampah terutama sampah pempers oleh masyarakat sekitar. Seorang tokoh masyarakat yang berinisiatif untuk menggerakkan kepedulian akan lingkungan bersih mulai mengajak masyarakat untuk bersama-sama menjaga kebersihan saluran irigasi sebagai upaya menjaga ekosistem yang muaranya akan ada simbiosis mutualisme yang akan saling menguntungkan. Dengan saluran irigasi sebagai media pengembangbiakan ikan, akan mampu menjual ikan dalam umur 6 bulan dari masa pembibitan. Selanjutnya POKDAKAN "Banyu Bening" juga memiliki Perpustakaan mini sebagai aset untuk meningkatkan kesadaran literasi budaya membaca di masyarakat sekaligus sebagai pembuka cakrawala ilmu pemgetahuan. Adanya Spiritual sebagai wadah perekat sosial kemasyarakatan juga akan meningkatkan kesadaran akan interaksi sosial.

Pada Tabel 2. Hasil penelusuran yang lebih mendalam (Apreciative Inquiry) bersama POKDAKAN "Banyu Bening" Desa Jajag dapat dijelaskan bahwa masyarakat yang memiliki masa lalu dengan saluran irigasi yang kotor dan menjadi tempat sampah, angker, kumuh, kurang produktif baik lahan maupun masyarakat dan hanya berkeinginan atau ide untuk melakukan pembersihan dan memanfaatan saluran irigasi. Pada akhirnya masa kini mampu diwujudkan dalam kondisi bersih, nyaman, adanya kolam ikan membuat ramai kunjungan masyarakat sebagai ajang hiburan, arena pancing ikan, arena bermain dan belajar, juga sebagai ajang "ngabuburit" (menunggu buka puasa) serta sebagai Spot selfie dan taman baca maka muncul juga kedai-kedai yang menyediakan makanan ringan serta homestay sebagai tempat penginapan pengunjung. Selain itu saluran irigasi yang digunakan untuk memelihara ikan sudah 
bersih menjadikan Petani sejahtera karena padi tumbuh subur akibat kotoran ikan dan air irigasi lancar. Kedepan ada harapan untuk bisa menbuatkan taman bermain ramah anak, Pengadaan souvenir (gantungan kunci, kaos dan assesoris lainnya) serta camilan khas (kuliner) Banyuwangi.

Tabel 2. Penemuan Apresiatif (Apreciative Inquiry) Pada POKDAKAN "Banyu Bening”

\begin{tabular}{|c|c|c|}
\hline Masa Lalu & Masa Kini & Masa Depan \\
\hline $\begin{array}{l}\text { 1. Kotor saluran } \\
\text { irigasinya, dan } \\
\text { menjadi tempat } \\
\text { sampah } \\
\text { 2. Angker } \\
\text { 3. Kumuh (busuk) } \\
\text { 4. Kurang produktif } \\
\text { baik lahan maupun } \\
\text { masyarakat } \\
\text { 5. Ide pembersihan } \\
\text { dan pemanfaatan } \\
\text { saluran irigasi. }\end{array}$ & $\begin{array}{l}\text { 1. Bersih, indah, nyaman } \\
\text { 2. Kolam ikan } \\
\text { 3. Ramai ajang hiburan } \\
\text { 4. Arena pancing ikan } \\
\text { 5. Arena bermain dan belajar } \\
\text { 6. Ajang ngabuburit/menunggu } \\
\text { buka puasa } \\
\text { 7. Spot selfie dan taman baca } \\
\text { 8. Bermunculan kedai-kedai } \\
\text { 9. Home stay } \\
\text { 10. Petani sejahtera karena padi } \\
\text { tumbuh subur akibat kotoran } \\
\text { ikan dan air irigasi lancar }\end{array}$ & $\begin{array}{l}\text { 1. Pengadaan souvenir } \\
\text { (gantungan kunci, } \\
\text { kaos dan assesoris } \\
\text { lainnya) } \\
\text { 2. Camilan khas } \\
\text { 3. Taman bermain } \\
\text { ramah anak }\end{array}$ \\
\hline
\end{tabular}

Sumber: wawancara Langsung pada komunitas POKDAKAN “Banyu Bening”, 2019

\section{Pemetaan Komunitas (Community Mapping)}

Kampung ikan "Banyu Bening" yang dikelola oleh Kelompok Pembudidaya Ikan (POKDAKAN) merupakan saluran air pertanian yang mengalir dari kanal buatan. Mengalir melintasi desa Wringinagung, desa Jajag dan desa Cluring. Pada saluran air tersebut dimanfaatkan oleh warga untuk memelihara ikan. Ada empat titik selokan yang dijadikan kolam ikan. Tiga titik ada di Dusun Krajan, yaitu Banyu Bening 1 sepanjang 200 meter yang berisi 16.000 ikan, Banyu Bening 2 sepanjang 250 meter dengan 8.000 ikan, Banyu Bening 3 sepanjang 400 meter berisi 8.000 ikan. Sedangkan satu titik selokan adalah Sumber Mulyo sepanjang 700 meter dan berisi 6.000 ikan di Dusun Bulusari. Ikan yang dipelihara antara lain jenis Koi, Tombro, Nila merah dan Nila hitam. Adapun detil data komunitas pengelola sebagaimana tersaji dalam Tabel 3.

Tabel 3. Pemetaan Komunitas (Community Mapping)

\begin{tabular}{clccc}
\hline No & \multicolumn{1}{c}{ Nama Asosiasi } & Nama & \multicolumn{2}{c}{ Jml Anggota } \\
\cline { 4 - 5 } & & Ketua & LK & PR \\
\hline 1 & Komunitas Banyu Bening 1 & Muyadi & 24 yang aktif 18 & - \\
\hline 2 & Komunitas Banyu Bening 2 & & & - \\
\hline 3 & Komunitas Banyu Bening 3 & & & - \\
\hline 4 & Sumber Mulyo & & & - \\
\hline
\end{tabular}

Sumber : wawancara Langsung pada Komunitas Banyu Bening, 2019 


\section{Pemetaan Aset Fisik dan Sumber Daya Alam}

Kampung Ikan "Banyu Bening" yang dikelola oleh Kelompok Pembudidaya Ikan (POKDAKAN) terletak di RT 4 dan RT 6 dusun Krajan Desa Jajag Gambiran Banyuwangi, berada di sebelah utara dari terminal Jajag, berjarak kurang lebih $100 \mathrm{~m}$ dan dibatasi oleh jalan beraspal. Kampung ikan "Banyu Bening" berada diperbatasan desa Jajag dan Wringinagung kecamatan Gambiran.

Di lokasi kampung ikan "Banyu Bening" yang posisinya membujur dari arah barat ke timur seluas kurang lebih $300 \mathrm{~m}$ persegi, disebelah utara yang merupakan wilayah RT 6 terdapat usaha batako, warung makan, kedai makanan dan minuman serta usaha kost yang berada disekitar rumah penduduk. Kolam pembudi daya ikan berada disisi selatan jalan yang merupakan wilayah RT 4 sepanjang $200 \mathrm{~m}$.

Di lokasi kolam terdapat tembok selfi, bale-bale yang terdapat perpustakaan mini, penjual pakan ikan serta kedai minuman. Sebelah area kolam terdapat home stay dan kost-kostan. Sebelah timur dari area kolam terdapat Mushola dan timur lagi terdapat pasar besar desa Jajag. Sedangkan pada sebelah barat lokasi yang merupakan wilayah desa Wringinagung terdapat masjid besar yang dapat digunakan untuk melakukan sholat Jum'at berjamaah, tepatnya pada sisi Barat Laut dari lokasi kampung ikan "Banyu Bening". Sedangkan di sebelah Barat Daya dari Kampung Ikan terdapat Kontor Pos Kecamatan Gambiran.

\section{Hasil}

\section{Pelaksanaan Pengabdian}

Setelah melakukan inkulturasi, pendekatan pada kelompok pembudidaya ikan pada proses pelaksanaan pengabdian dilakukan pada tanggal 19-21 Juli 2019. Kegiatan pengabdian ini dikemas dalam Sekolah Pengabdian dan Pelatihan Pengelolaan Literasi bagi POKDAKAN "Banyu Bening". Kegiatan sekolah pengabdian dilanjutkan dengan pelatihan pengembangan budaya literasi berbasis potensi lokal yang ada di lingkungan kampung ikan "Banyu Bening". Pelatihan ini diikuti oleh seluruh anggota dari Kelompok Pembudidaya Ikan (POKDAKAN) Kampung Ikan Banyu Bening yang berada di desa Jajag.

Sedangkan pemateri untuk Kegiatan Pelatihan pengembangan budaya literasi berbasis potensi lokal yang ada di lingkungan kampung Ikan Banyu Bening adalah LSM Rumah Literasi Banyuwangi, merupakan Lembaga swadaya masyarakat Rumah literasi Banyuwangi merupakan sebuah gerakan muda peduli yang mengkampanyekan budaya membaca yang ada di kabupaten Banyuwangi sebagai pemateri dan sekaligus pendamping bagi pengelolaan wisata literasi. 


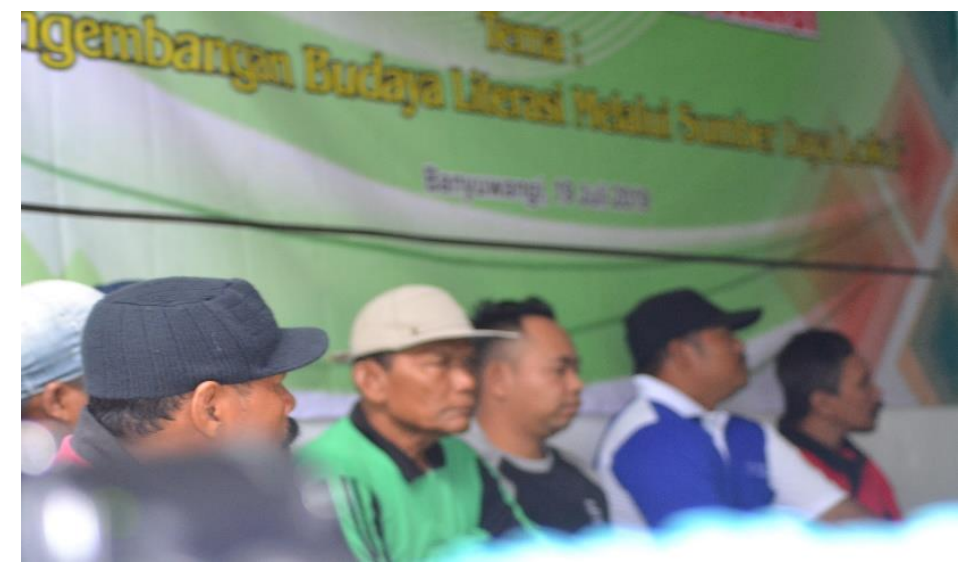

Gambar 2. Kegiatan pelatihan pengembangan budaya literasi berbasis potensi lokal

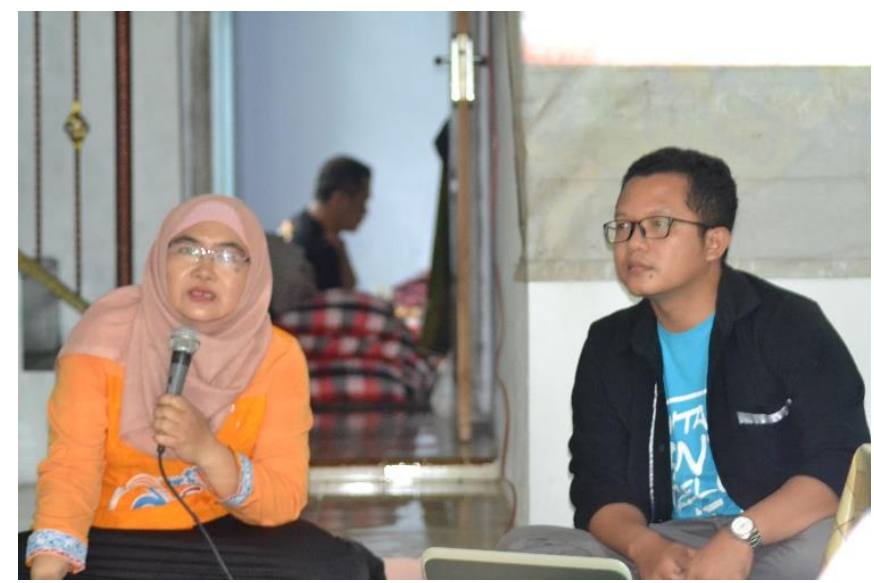

Gambar 3. Pemateri Bapak Ns. Tunggul Harwanto, M.Kes bersama ketua pelaksana

Pengabdian Nurul Inayah, SE., M.Si, dalam kegiatan pelatihan pengembangan budaya literasi berbasis potensi lokal

Dalam pelatihan pengembangan budaya literasi berbasis potensi lokal ini komunitas Pokdakan belajar bersama bagaimana cara membaca berbagai informasi bermanfaat, cara mengambil kesimpulan dari informasi yang dibaca, berlatih penilaian kritis terhadap suatu permasalahan yang ada di masyarakat. Selain itu, dalam pelatihan ini mereka juga sharing dan belajar bersama bagaimana mengembangkan sikap budi pekerti yang baik di dalam diri seseorang dan meningkatkan nilai kepribadian seseorang melalui kegiatan membaca dan menulis, Menumbuhkan dan mengembangkan budaya literasi di tengah-tengah masyarakat secara luas, dan membantu meningkatkan kualitas penggunaan waktu seseorang sehingga lebih bermanfaat.

Hasil kegiatan pelatihan pengembangan budaya literasi berbasis potensi lokal pada POKDAKAN kampung ikan "Banyu Bening", memiliki nilai manfaat untuk mengembangkan wisata literasi yang mampu menambah minat baca masyarakat pada buku-buku yang bermanfaat. Motivasi dan minat baca anak-anak semakin meningkat 
melalui pembiasaan budaya gemar membaca pada buku-buku yang bermanfaat, serta pengurus Pokdakan dapat menjadi pemandu wisata literasi dalam menjelaskan tentang bagaimana pembudidayaan ikan air tawar kepada para pelajar yang ingin belajar pembudidayaan ikan air tawar. Gambar 4. menunjukkan pengurus POKDAKAN yang menjadi pemandu wisata literasi.

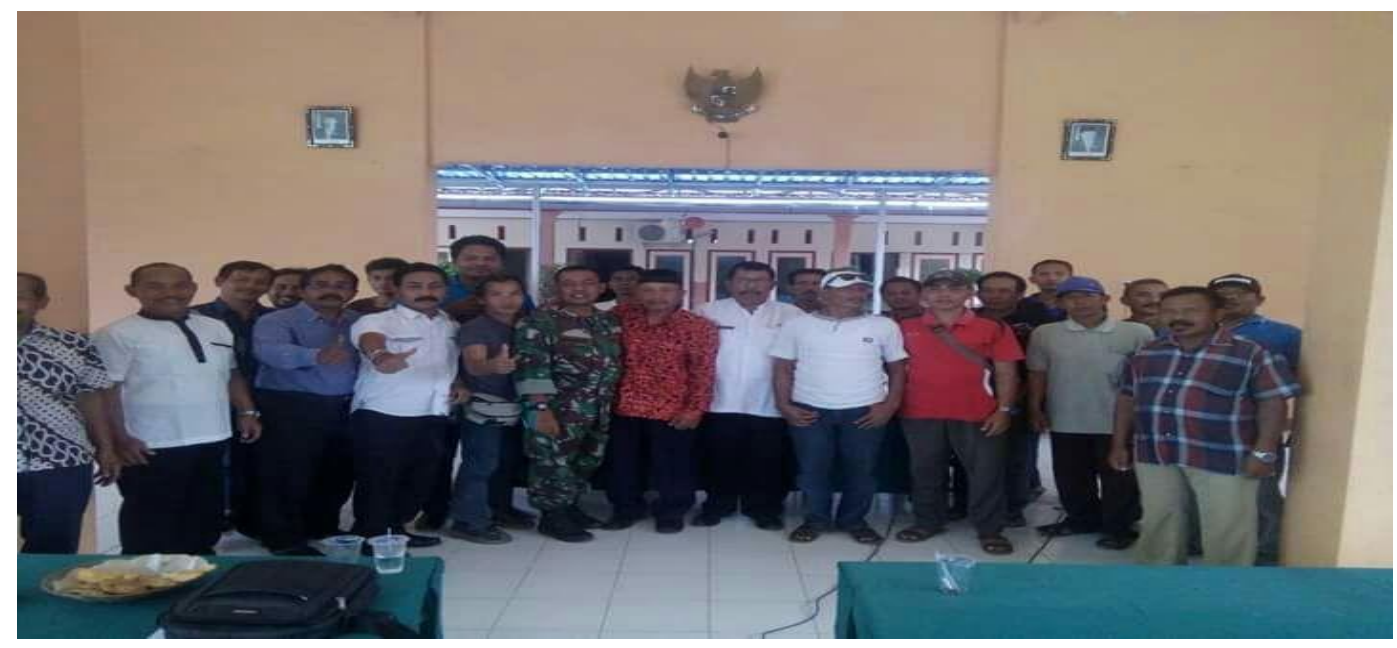

Gambar 4. Pengurus POKDAKAN yang Menjadi Pemandu Wisata Literasi

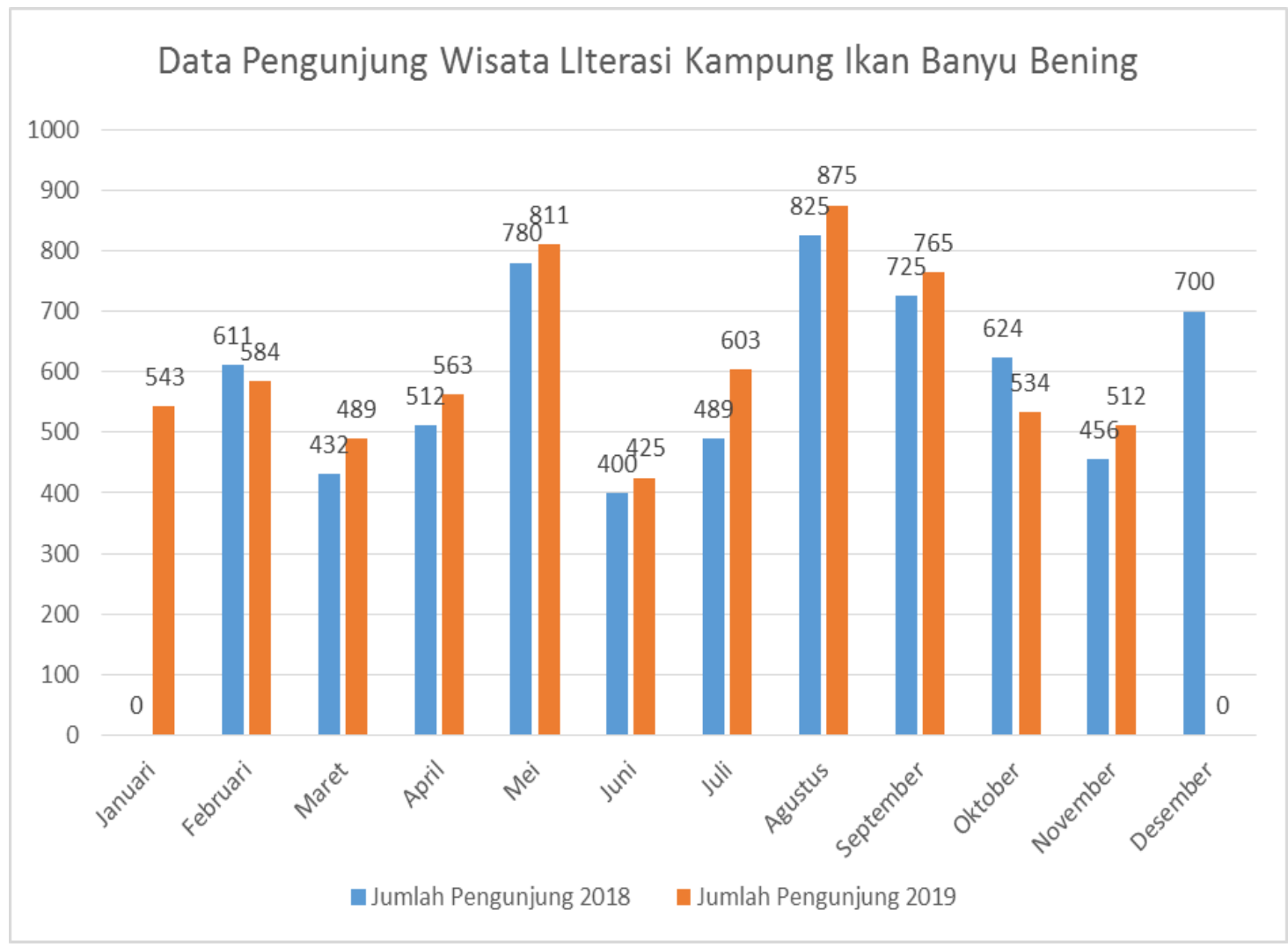

Gambar 5. Data Pengunjung Kampung Ikan Banyu Bening Tahun 2018-2019 


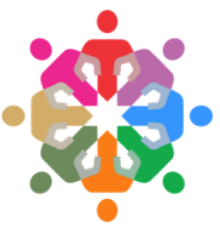

ENGAGEMENT

Jurnal Pengabdian kepada Masyarakat

Volume. 04, Number 01, May, 2020, pp. 252 - 265

Pada awal terbentuknya kampung ikan "Banyu Bening” mendapatkan respon yang positif dari masyarakat. Hal ini dapat dilihat dari jumlah pengunjung yang meningkat dari hari ke hari serta menjadikan kampung ikan "Banyu Bening" menjadi tempat wisata literasi bagi pelajar maupun umum. Jumlah pengunjung kampung ikan "Banyu Bening" dapat dilihat pada Gambar 5.

Pada Gambar 6. menunjukkan bahwa sebagian besar pengunjung wisata literasi merupakan para pelajar baik dari tingkat TK sampai tingkat SLTA yang ingin mengetahui bagaimana pembudidayaan ikan dengan memanfaatkan saluran irigasi. Selain itu, para pelajar juga dapat membaca buku buku yang disediakan oleh pokdakan terkait pembudidayaan ikan. Dan yang lebih menarik lagi, para pelajar dapat langsung mempraktikan cara budidaya ikan air tawar serta dapat memberi makan ikan yang ada di saluran irigasi.
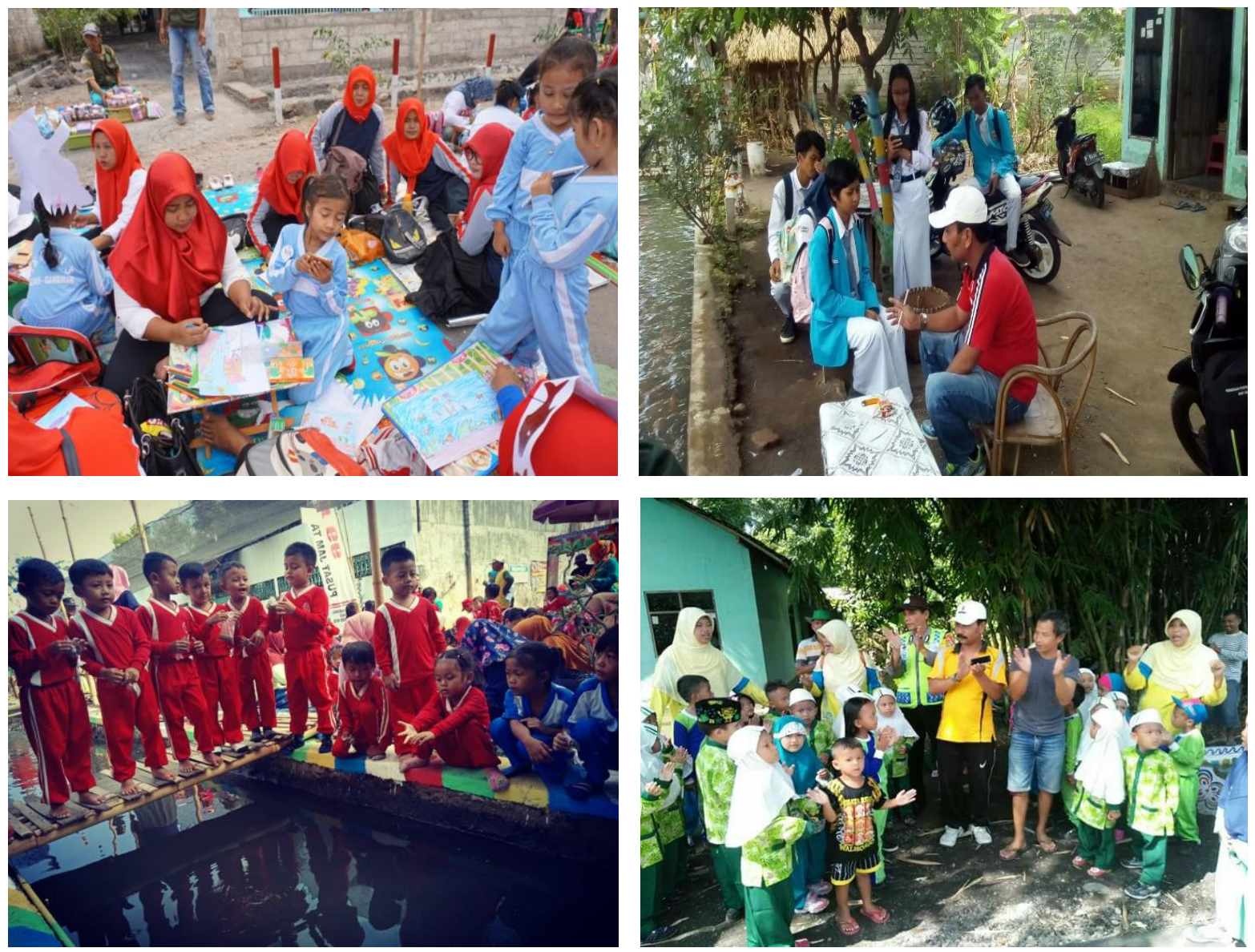

Gambar 6. Kunjungan Pelajar dalam Wisata Literasi Kampung Ikan “Banyu Bening” 


\section{Diskusi}

Kabupaten Banyuwangi yang berada di wilayah Provinsi Jawa Timur merupakan wiayah paling timur dari Pulau Jawa. Dan memiliki kawasan terluas di Jawa Timur, dengan mencapai 5.782,50KM melebihi Provinsi Bali yang hanya 5.636,66KM. Banyuwangi yang dijuluki kota Gandrung dikelilingi oleh garis pantai yang memanjang mulai dari Kecamatan Wongsorejo sampai dengan Kecamatan Pesanggaran memiliki pesisir pantai dan menjadi matapencaharian warga setempat sebagai nelayan.

Untuk itu pemerintah kabupaten Banyuwangi, berkomitmen untuk melakukan pembangunan disektor kelautan dan perikanan sebagai sektor unggulan dalam kancah internasional. Menurut Kurniawan, pembangunan di sektor kelautan dan perikanan, tidak boleh dipandang hanya sebagai cara untuk menghilangkan kemiskinan dan pengangguran. ${ }^{6}$ Namun, lebih dari itu, karena sektor kelautan dan perikanan merupakan basis perekonomian nasional, maka sudah sewajarnya jika sektor perikanan dan kelautan ini dikembangkan menjadi sektor unggulan dalam kancah perdagangan internasional, dengan demikian, dukungan sektor industri terhadap pembangunan di sektor perikanan dan kelautan menjadi suatu hal yang bersifat keharusan ${ }^{7}$.

Namun pada Februari 2011 Bupati Banyuwangi Abdullah Azwar Anas memaparkan bahwa produksi perikanan tangkap di Banyuwangi setiap tahunnya lebih dari 60 ribu ton. Pada tahun 2006 produksi meningkat sebesar 62 ribu ton dan tiap tahunnya menurun, hingga tahun 2008 hanya mencapai 40 ribu ton. Penurunan ini disebabkan antara lain terjadi over fishing terutama di sentra perikanan Muncar. Disamping itu ada kendala lain berupa pencemaran pesisir dan laut, belum optimalnya pengelolaan perikanan budidaya, abrasi akibat intrusi air laut, rendahnya penataan dan penegakan hukum serta degradasi ekosistem wilayah pesisir.

Ini menjadi tantangan bagi Bupati Banyuwangi, dan tantangan ini harus dihadapi bersama sebagai ikhtiar untuk mewujudkan Banyuwangi yang lebih baik. Jika mampu mengatasinya, maka berarti Banyuwangi telah berupaya meningkatkan kapasitas produksi perikanan, yang diestimasi kedepan akan terus meningkat per tahunnya sebesar 126 ribu ton. Bupati meminta dukungan semua pihak, yakni masyarakat dengan bersinergi antara pemerintah pusat dan pemerintah daerah ${ }^{8}$.

Pembangunan kawasan kelautan dan perikanan dikabupaten Banyuwangi dituangkan dalam Peraturan Daerah Kabupaten Banyuwangi Nomor 08 Tahun 2012 Tentang Rencana Tata Ruang Wilayah Kabupaten Banyuwangi Tahun 2012-2032, ${ }^{9}$ pada

6 Tony F Kurniawan, “Analisis Dan Reformasi Kebijakan Pembangunan Kelautan Dan Perikanan Di Indonesia" (PPNSI, 2010).

7 Ratna dkk, Pembangunan Minapolis Dan Hinterland Kawasan Minapolitan (Kabupaten Banyuwangi, 2012).

8 "Minapolitan Akan Timbulkan Multiplier Effect Ekonomi Banyuwangi," Pemerintah Kabupaten Banyuwangi, last modified 2011, accessed June 6, 2019, https://www.banyuwangikab.go.id/beritadaerah/minapolitan-akan-timbulkan-multiplier-effeck-ekonomi-banyuwangi.html.

${ }_{9}$ Bupati Kabupaten Banyuwangi, Peraturan Daerah Kabupaten Banyuwangi Nomor 08 Tahun 
Pasal 7 tentang Kebijakan Penataan Ruang Wilayah Kabupaten dan dijelaskan pada pasal 8 tentang Strategi Penataan Ruang Wilayah Kabupaten. Dijelaskan pada pasal 8 ayat 3, Pengembangan kawasan perikanan sebagaimana dimaksud dalam Pasal 7 ayat (2) huruf b dengan strategi meliputi dibutir ke d. mengoptimalkan pengembangan dan pengelolaan kawasan minapolitan; e. mengembangkan sentra-sentra produksi perikanan yang mendukung pengoptimalan industri pengolahan perikanan di kawasan minapolitan.

Minapolitan yang di kabupaten Banyuwangi difokuskan dan dipusatkan pada kecamatan Muncar pada pengembangan lanjutan diarahkan pada seluruh kecamatan yang memiliki potensi perikanan darat dan perikanan tangkap. Termasuk didesa Jajag yang memiliki Mina budidaya ikan air tawar dengan nama Gandoloka.

Pada mina budidaya ikan tawar desa Jajag memiliki beberapa spot pengelolaan yang disesuaikan dengan aliran sungai maupun saluran irigasi. Salah satu spot budidaya ikan air tawar yang ada adalah Kampung Ikan Banyu Bening. Dimana Kampung Ikan Banyu bening yang dikelola oleh Kelompok Pembudidaya Ikan (POKDAKAN) merupakan saluran air pertanian yang mengalir dari kanal buatan. Mengalir melintasi desa Wringinagung, desa Jajag dan desa Cluring. Pada saluran air tersebut dimanfaatkan oleh warga untuk memelihara ikan. Ada empat titik selokan yang dijadikan kolam ikan. Tiga titik ada di Dusun Krajan, yaitu Banyu Bening 1 sepanjang 200 meter yang berisi 16.000 ikan, Banyu Bening 2 sepanjang 250 meter dengan 8.000 ikan, Banyu Bening 3 sepanjang 400 meter berisi 8.000 ikan. Sedangkan satu titik selokan adalah Sumber Mulyo sepanjang 700 meter dan berisi 6.000 ikan di Dusun Bulusari. Ikan yang dipelihara antara lain jenis Koi, Tombro, Nila merah dan Nila hitam.

Dengan demikian, maka kampung ikan "Banyu Bening" yang dikelola oleh Kelompok Pembudidaya Ikan (POKDAKAN) telah memberikan kontribusi yang baik untuk sedikit mengurai permasalahan penurunan produksi ikan di Kabupaten Banyuwangi serta mengurai permasalahan pembuangan sampah liar pada saluran irigasi di desa Jajag menjadi kampung yang ramah lingkungan. ${ }^{10}$ Sedangkan wisata literasi telah mempu menjadi media edukasi yang sangat baik bagi masyarakat untuk terus mengembangkan sumber daya air secara baik dan tetap ramah lingkungan.

\section{Kesimpulan}

Pemanfaatan sumberdaya air irigasi menjadi wisata literasi di Kampung Ikan bening yang dikelola oleh Kelompok Pembudidaya Ikan (POKDAKAN) telah menjadi media edukasi dan peningkatan ekonomi masyarakat melalui budidaya ikan dalam air irigasi. Dengan penguatan kelembagaan dan pengembangan potensi ekonomi pada

2012 Tentang Rencana Tata Ruang Wilayah Kabupaten Banyuwangi Tahun 2012-2032 (Indonesia, 2012).

10 Silahkan baca Mulyono Wibisono et al., Kampung Eco-Green: Pemberdayaan Masyarakat

Melalui Integrated Community Development (ICD) Di Karangjati Pandaan Kabupaten Pasuruan (Kabupaten Pasuruan: Yudharta Press, 2016). 
komunitas POKDAKAN mereka memiliki kapasitas yang baik untuk pengembangan manajemen Kampung Ikan untuk mengoptimalkan sungai irigasi untuk pengembangan budidaya ikan sekaligus sebagai wisata literasi dengan dengan peningkatan pengurus POKDAKAN dapat menjadi pemandu wisata literasi dalam menjelaskan tentang bagaimana pembudidayaan ikan air tawar kepada para pelajar yang ingin belajar pembudidayaan ikan air tawar.

\section{Pengakuan}

Ucapan terimakasih kami sampaikan kepada Direktorat Pendidikan Tinggi Agama Islam Kementerian Agama Republik Indonesia yang telah memberikan kepercayaan kepada Tim dalam melaksanakan hibah pengabdian masyarakat, Bapak Suparno, SH, selaku Kepala Desa Jajag, Bapak Muyadi sebagai ketua Kelompok Pembudidaya Ikan (POKDAKAN) "Banyu Bening” Desa Jajag, serta berbagai pihak yang memberikan dukungan moril sehingga pengabdian ini berjalan dengan lancar.

\section{Daftar Referensi}

Bupati Kabupaten Banyuwangi. Peraturan Daerah Kabupaten Banyuwangi Nomor 08 Tahun 2012 Tentang Rencana Tata Ruang Wilayah Kabupaten Banyuwangi Tahun 2012-2032. Indonesia, 2012.

Dewi, I K. "Model Pengelolaan Kawasan Permukiman Berkelanjutan Di Daerah Aliran Sungai (DAS) Ciliwung Hulu Kabupaten Bogor." Doctoral Dissertation, Institut Pertanian Bogor, 2010.

Kepala Desa Jajag Gambiran Banyuwangi. Peraturan Desa Jajag Gambiran Banyuwangi No.1 Tahun 2008 Tentang Pelarangan Warga Untuk Melakukan Penyetruman, Menjala Ikan, Dan Penggunaan Obat-Obatan Disepanjang Irigasi Sungai Desa. Indonesia, 2008.

Kurniawan, Tony F. "Analisis Dan Reformasi Kebijakan Pembangunan Kelautan Dan Perikanan Di Indonesia." PPNSI, 2010.

M.B., Hadimulyono. "Kebijakan Pengeloaan Suberdaya Air Menurut Undang-Undang Tengtang Sumber Daya Air Dalam Perepesktif Menunjang Pembanguan Pertanian." Bogor: Deptan Bogor, 2004.

Ratna dkk. Pembangunan Minapolis Dan Hinterland Kawasan Minapolitan. Kabupaten Banyuwangi, 2012.

Salahuddin, Nadhir. "Panduan KKN ABCD UIN Sunan Ampel Surabaya Asset Based Community-Driven Development (ABCD)." Surabaya: LP2M UIN Sunan Ampel Surabaya, 2015.

Wibisono, Mulyono, Syukur Sugeng Apriwiyanto, Amang Fathurrohman, and Zainul Ahwan. Kampung Eco-Green: Pemberdayaan Masyarakat Melalui Integrated Community Development (ICD) Di Karangjati Pandaan Kabupaten Pasuruan. 
Kabupaten Pasuruan: Yudharta Press, 2016.

"Minapolitan Akan Timbulkan Multiplier Effect Ekonomi Banyuwangi." Pemerintah Kabupaten Banyuwangi. Last modified 2011. Accessed June 6, 2019. https://www.banyuwangikab.go.id/berita-daerah/minapolitan-akan-timbulkanmultiplier-effeck-ekonomi-banyuwangi.html. 